\title{
The association of the hepatitis B virus infection with thyroid carcinoma: a large sample clinical study in China
}

\author{
Wei Dai, ${ }^{1,}$, Yu-Tuan Wu ${ }^{2, *}$, Xin $\mathrm{Li}^{2, *}$, Yan-Ling Shi', ${ }^{2,}$ Lu Gan ${ }^{3}$, Hong-Yuan $\mathbf{L i}^{2}$, \\ Guo-Sheng Ren ${ }^{2}$, Kai-Nan $\mathbf{W u}^{2}$ and Ling-Quan Kong ${ }^{2}$ \\ ${ }^{1}$ Department of Surgery, The Second Affiliated Hospital of Chongqing Medical University, Chongqing 400010, China \\ ${ }^{2}$ Department of Endocrine and Breast Surgery, The First Affiliated Hospital of Chongqing Medical University, Chongqing \\ 400016, China \\ ${ }^{3}$ Department of Oncology and Radiology, The First Affiliated Hospital of Chongqing Medical University, Chongqing 400016, \\ China \\ *These authors contributed equally to this work \\ Correspondence to: Ling-Quan Kong, email: huihuikp@163.com \\ Keywords: hepatitis B core antibody; hepatitis B virus; past infection; thyroid carcinoma; thyroid stimulating hormone \\ Received: July 12, $2017 \quad$ Accepted: December 05, $2017 \quad$ Published: January 02, 2018 \\ Copyright: Dai et al. This is an open-access article distributed under the terms of the Creative Commons Attribution License 3.0 \\ (CC BY 3.0), which permits unrestricted use, distribution, and reproduction in any medium, provided the original author and source \\ are credited.
}

\section{ABSTRACT}

Objective: To explore whether thyroid carcinoma is associated with the infection of hepatitis B virus.

Results: Although there were no differences on the positive rates of Hepatitis B surface antigen and hepatitis B surface antibody in the thyroid carcinomas group $(8.67 \% \& 59.24 \%)$ and control group $(8.86 \% \& 58.21 \%, p>0.05)$, the positive rate of hepatitis B core antibody in thyroid carcinomas group $(55.71 \%)$ was significantly lower than that in the control group $(63.28 \%, p=0.0004)$. Through the logistic regression analysis, compared to the control group, the rate of hepatitis $B$ core antibody seropositivity was lower in thyroid carcinomas group in whole cases (Adjusted $O R=0.82,95 \% C I 0.69-0.98, p=0.0337$ ). In addition, compared to the control group, a more interesting result was found that the adjusted $O R$ value of hepatitis $B$ core antibody seropositivity of male is lower than female in statistics (Adjusted OR $=0.62,95 \%$ CI 0.41-0.94, $p=0.0237 ;$ Adjusted OR $=0.89,95 \%$ CI $0.72-1.08, p>0.05$, respectively).

Conclusions: The rate of hepatitis B core antibody seropositivity in thyroid carcinoma patients is lower than that in controls and the past hepatitis B virus infection may be a weak protective factor for the development of thyroid carcinoma.

Methods: In this study, the clinical data of 2134 patients with initially diagnosis of thyroid nodules while receiving surgery, with the reports of hepatitis B virus serological markers in single center from June 2010 to September 2015, were collected for comparative analysis. Of all there were $1050(49.20 \%)$ cases of thyroid carcinomas group and $1084(50.80 \%)$ noncancerous thyroid nodules group.

\section{INTRODUCTION}

Thyroid carcinoma (TC) is one of the most common endocrine malignancies. Compared with the estimated ratio of incidence of thyroid carcinoma collected from new cases of invasive cancer in Chinese female, which accounts for $3.8 \%$ [1], the number of it derived from developed countries is much higher [2]. All these data prove that prevention and treatment of thyroid carcinoma still can not be ignored. The incidence of thyroid 
carcinoma has increased significantly during recent years $[1,2]$, which could be connected with increased detection and increased number of cases due to thyroid-specific carcinogens, such as radiation exposure and increased iodine intake [3]. Although viruses are second only to tobacco as a risk factor for cancer [4], little is known regarding viral infections in thyroid carcinoma. Hepatitis virus is one of commonest causes of viral infection worldwide. In western countries, hepatitis $\mathrm{C}$ virus (HCV) infection is common, but in China, an epidemic area with a high or moderate rate of hepatitis B virus (HBV) infection [5], HBV infection is more common than HCV. Some studies [6-8] by Western scholars indicate that thyroid carcinoma might be associated with $\mathrm{HCV}$ infection. However, whether thyroid carcinoma is associated with $\mathrm{HBV}$ infection had remained unclear.

In this paper, the status of HBV infection among patients with initially diagnosed thyroid carcinoma and noncancerous thyroid nodules is studied to explore whether thyroid carcinoma is associated with the infection of HBV.

\section{RESULTS}

\section{Study population}

In this study, we enrolled 2134 eligible cases, and divided them into two groups, thyroid carcinoma group (TC group) and noncancerous controls group (control group). In all cases, 1050 thyroid carcinoma cases in TC group, including 1005 papillary carcinoma (95.71\%), 14 follicular carcinoma $(1.33 \%), 7$ anaplastic carcinoma $(0.67 \%)$ and 24 others $(2.29 \%)$, and 1084 noncancerous cases in control group were collected for comparative analysis (Table 1).

The average age and gender were significantly different between TC and control group ( $p<0.05)$. Compared with the control group, the male-to-female ratio in TC group was significantly higher (274 vs. 776, 210 vs. $874, p=0.0003$ ). The average age of the initially diagnosed thyroid carcinoma patients was $44.34 \pm$ 13.81 years, which was significantly lower than that in noncancerous control $(48.81 \pm 12.94$ years; $p<0.0001)$. The following table described the number of cases of the different age groups ( $\leq 29$ years age group, $30-39$ years age group, 40-49 years age group, 50-59 years age group, $\geq 60$ years age group) (Table 1 ).

\section{Comparison of $\mathrm{HBV}$ infection in the TC group and control group}

The Table 2 summarized the results of the comparisons of HBV serological markers in the TC group and the matched control group. Although there were no differences on the positive rates of $\mathrm{HBsAg}$ and $\mathrm{HBsAb}$ in the TC group $(8.67 \%$ \& $59.24 \%)$ and control group
$(8.86 \% \& 58.21 \%, p>0.05)$, the positive rate of $\mathrm{HBcAb}$ in TC group was significantly lower than that in control group $(55.71 \%$ vs. $63.28 \% ; p=0.0004)$. The possible confounding effects caused by age and gender were controlled by the stratification for age and gender. For male and female, the positive rates of $\mathrm{HBcAb}$ in TC groups were both significantly lower than those in control groups (57.30\% vs. $73.81 \%, p=0.0002 ; 55.15 \%$ vs. $60.76 \%$, $p=0.0214$, respectively). Analysis based on age stratification showed that there were no significant differences on the positive rate of $\mathrm{HBcAb}$ among the female different age groups, but the $p$-value of positive rate of $\mathrm{HBcAb}$ was close to 0.05 in $30-39$ years age group ( $p=$ 0.0510 ). Moreover, in 50-59 years age group , the positive rate of HBsAg in TC group was significantly lower than that in control group ( $4.67 \%$ vs. $10.58 \% ; p=0.0432)$.

Through the logistic regression analysis, compared to the control group, the rate of $\mathrm{HBcAb}$ seropositivity was lower in TC group in whole cases (Adjusted OR $=0.82$, $95 \%$ CI 0.69-0.98, $p=0.0337$ ). In addition, compared to the control group, a more interesting result was found that the adjusted $O R$ value of $\mathrm{HBcAb}$ seropositivity of male is lower than female in statistics (Adjusted OR $=0.62,95 \%$ CI 0.41-0.94, $p=0.0237$; Adjusted $O R=0.89,95 \% C I$ $0.72-1.08, p>0.05$, respectively) (Table 3 ).

\section{DISCUSSION}

The hepatitis virus infection constitutes one of the major global public health problems. According to the World Health Organization (WHO), more than 185 million people around the world have been infected with $\mathrm{HCV}$, of whom 350,000 die each year [9-11]. It is estimated that worldwide, 2 billion people have evidence of past or present infection with HBV, and 240 million are chronic carriers of HBsAg $[12,13]$. Many studies regarding the association between hepatitis virus and cancers have published, but to our knowledge, few studies concerning the association of thyroid carcinoma with HBV infection has been published to data. This is a large sample study to explore the role of HBV infection in patients with thyroid carcinoma.

The study revealed thyroid carcinoma and noncancerous thyroid nodules occur 2.84 times and 4.14 times, respectively, more common in female than in male (776 vs. 274,874 vs. $210 ; p=0.0003$ ), as similar with other literature [14]. The average age of the initially diagnosed thyroid carcinoma patients was $44.34 \pm$ 13.81 years, which was significantly lower than that in noncancerous control (48.81 \pm 12.94 years; $p<0.0001)$. In order to better compare HBV markers, multiple layer analysis and logistic regression analysis were conducted for age and/or gender.

For HBV-infected patients, the eradication of $\mathrm{HBV}$ infection is difficult, because the genome of HBV is composed of partially double-stranded DNA that is 
Table 1: Study population characteristics in thyroid carcinoma and noncancerous controls groups

\begin{tabular}{|c|c|c|c|}
\hline & $\mathbf{T C}$ & Control & $p$-value \\
\hline Total number of patients & 1050 & 1084 & \\
\hline Male/Female & $274 / 776(1: 2.83)$ & $210 / 874(1: 4.16)$ & 0.0003 \\
\hline Age (mean $\pm \mathrm{SD}, \mathrm{y})$ & $44.34 \pm 13.81$ & $48.81 \pm 12.94$ & $<0.0001$ \\
\hline \multicolumn{4}{|l|}{ Age (M\&F) } \\
\hline$\leq 29$ & 163 & 81 & \\
\hline $30-39$ & 215 & 165 & \\
\hline $40-49$ & 317 & 333 & \\
\hline $50-59$ & 193 & 263 & \\
\hline$\geq 60$ & 162 & 242 & \\
\hline \multicolumn{4}{|l|}{ Age (F) } \\
\hline$\leq 29$ & 115 & 72 & \\
\hline $30-39$ & 144 & 138 & \\
\hline $40-49$ & 244 & 265 & \\
\hline $50-59$ & 150 & 208 & \\
\hline$\geq 60$ & 123 & 191 & \\
\hline \multicolumn{4}{|l|}{ Pathological type of TC } \\
\hline Papillary carcinoma & $1005(95.71 \%)$ & & \\
\hline Follicular carcinoma & $14(1.33 \%)$ & & \\
\hline Anaplastic carcinoma & $7(0.67 \%)$ & & \\
\hline Others & $24(2.29 \%)$ & & \\
\hline \multicolumn{4}{|l|}{ Pathological type of control } \\
\hline Thyroid adenoma & & $580(53.51 \%)$ & \\
\hline Nodular goiter & & $436(40.22 \%)$ & \\
\hline TA and NG & & $68(6.21 \%)$ & \\
\hline
\end{tabular}

Abbreviations: SD, standard deviation; y, year; M,male; F, female; TA: Thyroid adenoma; NG: Nodular goiter.

converted to cccDNA in infected hepatocyte [15], and HBV DNA becomes integrated into the host genome, which indicates the presence of ongoing viral replication $[16,17]$. After many years of acute HBV infection, even with the clearance of serum HBsAg and the presence of HBsAb, HBV DNA was still detected in liver, which means that $\mathrm{HBV}$ replication may continue and persist for decades as an occult infection [18-20]. It is reported that persistent covalently closed circular(cccDNA) can be detected even in the peripheral blood of HBsAgnegative patients with resolved hepatitis B infections $[15$, 20]. All this indicates that $\mathrm{HBcAb}$ may more accurately reflect the long-term subtle influence of $\mathrm{HBV}$ infection on thyroid carcinoma than HBsAg. In addition, the $\mathrm{HBcAb}$ seropositivity is important past $\mathrm{HBV}$ infection indications, it is detected in both acute and chronic HBV infection [13].

We found that there are no differences on the positive rates of $\mathrm{HBs} \mathrm{Ag}$ and $\mathrm{HBsAb}$ in the TC group and control group, but the positive rate of $\mathrm{HBcAb}$ in patients with thyroid carcinoma is significantly lower than that in patients with noncancerous thyroid nodules, according to a whole or sex-stratification analysis (see Table 2). In addition, logistic regression analysis found that the rate of $\mathrm{HBcAb}$ seropositivity in thyroid carcinoma patients was still lower than that in controls (Adjusted OR $=0.82,95 \%$ $C I$ 0.69-0.98, $p=0.0337$ ). Consequently, these suggest that past $\mathrm{HBV}$ infection may be a weak protective factor for the development of thyroid carcinoma. The results is in sharp contrast with other report in the literature which showed that HBV infection increases the risk of thyroid carcinoma, but it is important to note that there are only 14 cases with HBV infection and thyroid carcinoma in the Kristina Sundquist et al. study [21]. Moreover, the sample is derived from Sweden with low prevalence of HBV infection, which may be lead to bias. Some studies have explored the relationship between $\mathrm{HCV}$ infection and thyroid carcinoma, these study results suggest that $\mathrm{HCV}$ infection may be the risk factor for thyroid carcinoma [6-8], but some others do not confirm these results [22-24]. Moreover, HBV and HCV are both hepatitis virus, and there exist similarity between them, but it should be noted that HCV is a RNA virus that cannot be integrated with the host genome [25].

It is interesting to note that the $O R$ value of $\mathrm{HBcAb}$ seropositivity of male is lower than female in statistics 
Table 2: Comparison of HBV seropositivity in thyroid carcinoma group and control group

\begin{tabular}{|c|c|c|c|c|c|c|}
\hline & \multicolumn{5}{|c|}{ HBV serological markers (positive rate \%) } & \multirow{2}{*}{$\begin{array}{c}\text { Significant } \\
p \text {-value }\end{array}$} \\
\hline & $\begin{array}{c}\text { HBsAg+ } \\
\text { TC/Control }\end{array}$ & $\begin{array}{c}\text { HBsAb+ } \\
\text { TC/Control }\end{array}$ & $\begin{array}{c}\text { HBeAg+ } \\
\text { TC/Control }\end{array}$ & $\begin{array}{c}\text { HBeAb+ } \\
\text { TC/Control }\end{array}$ & $\begin{array}{c}\text { HBcAb+ } \\
\text { TC/Control }\end{array}$ & \\
\hline Whole & $8.67 / 8.86$ & $59.24 / 58.21$ & $0.86 / 0.46$ & $26.38 / 28.69$ & $55.71 / 63.28 \mathrm{a}$ & 0.0004 \\
\hline \multicolumn{7}{|l|}{ Gender } \\
\hline Male & $9.85 / 10.48$ & $60.22 / 62.38$ & $1.46 / 0$ & $28.83 / 32.38$ & $57.30 / 73.81 \mathrm{a}$ & 0.0002 \\
\hline Female & $8.25 / 8.47$ & $58.89 / 57.21$ & $0.65 / 0.57$ & $25.52 / 27.80$ & $55.15 / 60.76 a$ & 0.0214 \\
\hline \multicolumn{7}{|l|}{$\operatorname{Age}(\mathrm{F})$} \\
\hline$\leq 29$ & $2.61 / 8.33$ & $57.39 / 54.17$ & $0.87 / 0$ & $20.87 / 22.22$ & $26.09 / 33.33$ & - \\
\hline $30-39$ & $11.11 / 10.14$ & $63.19 / 65.94$ & $0.69 / 1.45$ & $23.61 / 29.71$ & $49.31 / 60.87 b$ & - \\
\hline $40-49$ & $9.43 / 6.04$ & $57.38 / 59.25$ & $0.82 / 1.13$ & $28.69 / 28.30$ & $60.25 / 62.26$ & - \\
\hline $50-59$ & $4.67 / 10.58 \mathrm{a}$ & $62.67 / 56.25$ & $0 / 0$ & $24.67 / 26.92$ & $61.33 / 63.46$ & 0.0432 \\
\hline$\geq 60$ & $12.20 / 8.38$ & $53.66 / 50.26$ & $0.81 / 0$ & $26.83 / 28.80$ & $71.54 / 65.97$ & - \\
\hline
\end{tabular}

Abbreviation: F, female.

Data are expressed as number (percentage) unless otherwise specified.

a There were differences in statistic ( $p<0.05$, by student's test of independent sampler).

${ }^{\mathrm{b}} p$-value equals 0.0510 .

Table 3: Odds ratio and corresponding $95 \%$ confidence intervals of cases by $\mathrm{HBcAb}$ seropositivity

\begin{tabular}{|c|c|c|c|c|c|c|}
\hline & \multicolumn{2}{|c|}{$\mathbf{H B c} \mathbf{A} b^{b}$} & \multirow{2}{*}{ Total } & \multirow{2}{*}{ Adjusted OR } & \multirow{2}{*}{$95 \% \mathrm{CI}$} & \multirow{2}{*}{$p$-value } \\
\hline & Positive $n(\%)$ & Negative $n(\%)$ & & & & \\
\hline Whole & & & & 0.82 & $(0.69,0.98)$ & 0.0337 \\
\hline $\mathrm{TC}$ & $585(46.03)$ & $465(53.88)$ & 1050 & & & \\
\hline Control & $686(53.97)$ & $398(46.12)$ & 1084 & & & \\
\hline Total & 1271 & 863 & 2134 & & & \\
\hline $\operatorname{Sex}(M)$ & & & & 0.62 & $(0.41,0.94)$ & 0.0237 \\
\hline $\mathrm{TC}$ & $157(50.32)$ & $117(68.02)$ & 274 & & & \\
\hline Control & $155(49.68)$ & $55(31.98)$ & 210 & & & \\
\hline Total & 312 & 172 & 484 & & & \\
\hline $\operatorname{Sex}(F)$ & & & & 0.89 & $(0.72,1.08)$ & - \\
\hline $\mathrm{TC}$ & $428(44.63)$ & $348(50.36)$ & 776 & & & \\
\hline Control & $531(55.37)$ & $343(49.64)$ & 874 & & & \\
\hline Total & 959 & 691 & 1650 & & & \\
\hline
\end{tabular}

Abbreviations: F, female; M, male.

${ }^{a}$ Adjusted OR used control cohort as the reference cohort. Adjusted factors included age and/or gender.

${ }^{\mathrm{b}}$ The seropositivity of $\mathrm{HBcAb}$ was used to understand past HBV infection.

(Adjusted OR $=0.62,95 \%$ CI 0.41-0.94, $p=0.0237$

Adjusted $O R=0.89,95 \%$ CI $0.72-1.08, p>0.05$, respectively). The protective effect of past HBV infection on thyroid carcinoma in male may be stronger factor than in female. It suggests that the gender difference may be connected to the protective effect.

From what our study have mentioned above, we surmise, the past HBV infection may be a weak protective factor for thyroid carcinoma. Its possible mechanism may be that HBV may persist as an occult infection, and HBV replication may continue to cause long-term subtle liver dysfunction, after HBV infection [18-20]. Estrogen is mainly deactivated in the liver. Therefore, estrogen may increase due to liver dysfunction. We make for the bold conjecture that increasing estrogen level on the basis of original one may inhibit thyroid stimulating hormone (TSH) level from the pituitary by feedback mechanism of hypothalamus-pituitary axis. TSH is a trophic hormone that can stimulate the growth of cells derived from thyroid follicular epithelium, High TSH levels as a carcinogenic factor of thyroid carcinoma is generally considered [14]. Reducing TSH level can inhibit the growth of thyroid 
follicular epithelium cells to protected thyroid gland from thyroid carcinoma threat (Figure 1). Moreover, others may play important roles in the explanation also, such as the immunological mechanism, genomic mechanism and environment. However, further study is needed to confirm our hypothesis and increase sample sizes.

The strengths and limitations of our study should be considered. The strengths include the large size of the cohort, which was represented by a large segment of the population of southwest China, and the complete records of serological markers for $\mathrm{HBV}$ tests. $\mathrm{HBcAb}$ was mainly observed in the research, which can more accurately reflect the long-term subtle influence of $\mathrm{HBV}$ infection on thyroid carcinoma than HBsAg. Unfortunately, we could not include additional serum markers (HBV DNA) that would show the severity of HBV infection, and the use of an additional healthy population as a control group may improve the preciseness of the results.

In conclusion, the current data about the relationship between HBV infection and the risk of thyroid carcinoma is scarce, and our study showed that the rate of $\mathrm{HBcAb}$ seropositivity in thyroid carcinoma patients is lower than that in controls and the past hepatitis B virus infection may be a weak protective factor for the development of thyroid carcinoma, especially for male.

\section{METHODS}

\section{Data sources and exclusion criteria}

This retrospective study was based on hospitalized patients with initially diagnosis of thyroid nodules in the First Affiliated Hospital of Chongqing Medical University from June 2010 to September 2015. Approximately 31.4 million people live in the 82402.95 $-\mathrm{km}^{2}$ area of Chongqing in southwest China. These patients underwent surgery for histologically-confirmed thyroid carcinoma or noncancerous thyroid nodules. Cases diagnosed with $\mathrm{HCV}$, treponema pallidum, human immunodeficiency virus infection and other cancers were excluded from this study. For noncancerous control, the exclusion criteria included histologically-confirmed Hashimoto's thyroiditis and other malignant potential in histology.

\section{Study design}

In China, all surgical patients must undergo routine examination for serological markers of HBV tests for perioperative preparation. Because $\mathrm{HBV}$ infection is very popular in China, it was required that the $\mathrm{HBV}$

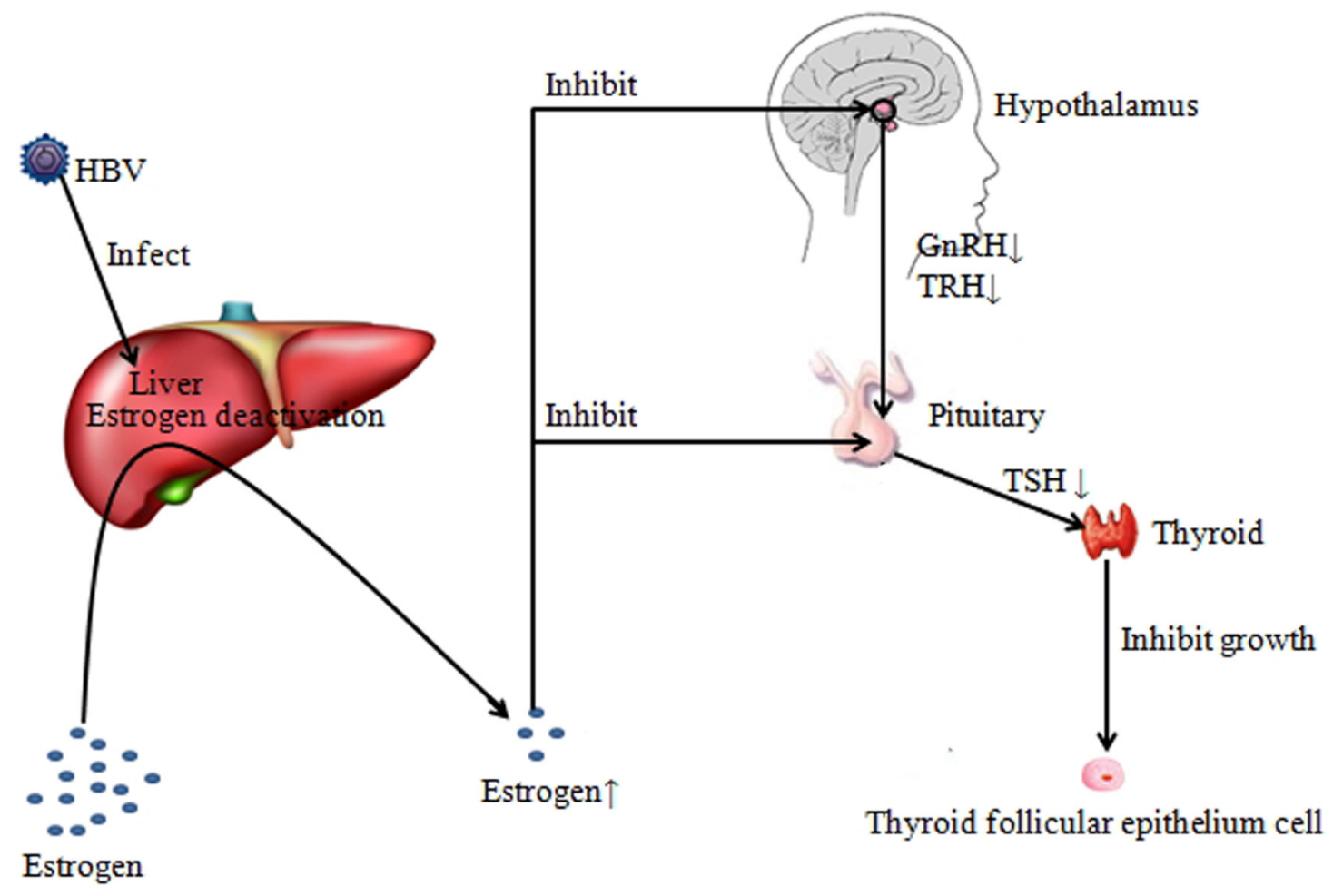

Figure 1: Possible mechanism of the protection of past HBV infection on thyroid carcinoma. A part of liver function are damaged, when infecting HBV, which caused decreasing for estrogen deactivation in the liver, leading to increase of peripheral blood estrogen level. For the peripheral blood of HBsAg-negative patients with resolved hepatitis B infections, traces of HBV may also maintain low level liver dysfunction. Increasing estrogen level on the basis of original one may inhibit TSH level from the pituitary by feedback mechanism of hypothalamus-pituitary axis. Reducing TSH level can inhibit the growth of thyroid follicular epithelium cells to protected thyroid gland from thyroid carcinoma threat. 
serological markers should be investigated in every preoperative patient. The following examinations were performed before surgery: HBV serological markers, HCV antibody, human immunodeficiency virus antibody and treponema pallidum antibody. The differences between the preoperative clinical data included general information and HBV serological markers, of the two groups were analyzed by the corresponding statistical methods. All patients provided informed consent to allow their case records to be used for medical research. The retrospective study protocol was approved by the Ethics Committee of the First Affiliated Hospital of Chongqing Medical University.

\section{Analytical measurements and standard}

The HBV serological markers included hepatitis B surface antigen (HBsAg), hepatitis B surface antibody (HBsAb), hepatitis B e antigen ( $\mathrm{HBeAg}$ ), hepatitis B e antibody $(\mathrm{HBe} A b)$ and hepatitis $\mathrm{B}$ core antibody ( $\mathrm{HBcAb})$. $\mathrm{HBsAg}$ (negative range: titer $\leq 0.04 \mathrm{IU} / \mathrm{ml}$ ) and $\mathrm{HBsAb}$ (negative range: titer $\leq 10 \mathrm{mIU} / \mathrm{ml}$ ) were tested by timeresolved fluoroimmunoassay (TRFIA). HBeAg (negative range: (optical density to cut off value ratio $<1.0$ ), $\mathrm{HBeAb}$ (negative range: optical density to cut off value ratio $\geq 1.0$ ) and $\mathrm{HBcAb}$ (negative range: optical density to cut off value ratio $<1.0$ ) were detected with the use of enzyme linked immunosorbent assay (ELISA).

\section{Control}

Blood samples were measured at The Clinical Laboratories of The First Affiliated Hospital of Chongqing Medical University (ISO 15189 accreditation and College of American Pathologists Proficiency Test Accreditation). The laboratory successfully completed the standardization and certification program. All the patients' records, including HBV serological markers tests, were available in the Electronic Medical Records of center.

\section{Statistical analysis}

Data were presented as mean $\pm \mathrm{SD}$. For continuous numerical variable, such as age, group differences were tested by student's test. Group differences were tested by Chi-square test or Fisher's exact test, for categorical variable, the positive rate of HBV serological markers. The relationship between thyroid carcinoma and $\mathrm{HBcAb}$ was assessed by means of adjusted odds ratio $(O R)$ and the corresponding 95\% confidence interval. Multiple layer analysis and logistic regression analysis were conducted to improve the precision. All raw data were inputted with Microsoft Office Excel 97-2003. All statistical analyses were performed with IBM SPSS statistics software (version 20.0). $P$-value of $<0.05$ was considered significant.

\section{ACKNOWLEDGMENTS}

We thank the patients for participating in this study. This study was carried out through the provision of data by the Chongqing Medical University, China. The opinions, results, and conclusions reported in this article are those of the authors.

\section{CONFLICTS OF INTEREST}

None of the authors have any potential conflicts of interest associated with this research.

\section{REFERENCES}

1. Chen W, Zheng R, Baade PD, Zhang S, Zeng H, Bray F, Jemal A, Yu XQ, He J. Cancer statistics in China, 2015. CA Cancer J Clin. 2016; 66:115-32. https://doi.org/10.3322/ caac. 21338.

2. Siegel RL, Miller KD, Jemal A. Cancer statistics, 2016. CA Cancer J Clin. 2016; 66:7-30. https://doi.org/10.3322/ caac. 21332.

3. Vigneri R, Malandrino P, Vigneri P. The changing epidemiology of thyroid cancer: why is incidence increasing? Curr Opin Oncol. 2015; 27:1-7. https://doi. org/10.1097/CCO.0000000000000148.

4. Talbot SJ, Crawford DH. Viruses and cancer. Medicine. 2009; 37:541-4. https://doi.org/10.1016/j. mpmed.2009.07.009.

5. Liang X, Bi S, Yang W, Wang L, Cui G, Cui F, Zhang Y, Liu J, Gong X, Chen Y, Wang F, Zheng H, Wang F, et al. Epidemiological serosurvey of hepatitis B in China-declining HBV prevalence due to hepatitis B vaccination. Vaccine. 2009; 27:6550-7. https://doi.org/10.1016/j. vaccine.2009.08.048.

6. Antonelli A, Ferri C, Fallahi P. Thyroid cancer in patients with hepatitis C infection. JAMA. 1999; 281:1588. https:// doi.org/10.1001/jama.281.17.1588.

7. Antonelli A, Ferri C, Fallahi P, Pampana A, Ferrari SM, Barani L, Marchi S, Ferrannini E. Thyroid cancer in HCV-related chronic hepatitis patients: a case-control study. Thyroid. 2007; 17:447-51. https://doi.org/10.1089/ thy.2006.0194.

8. Montella M, Pezzullo L, Crispo A, Izzo F, Amore A, Marone U, Tamburini M, Ronga D, Chiofalo MG, Chiappetta G, Mozzillo N. Risk of thyroid cancer and high prevalence of hepatitis C virus. Oncol Rep. 2003; 10:133-6. https://doi. org/10.3892/or.10.1.133.

9. Lavanchy D. The global burden of hepatitis C. Liver Int. 2009; 29:74-81. https://doi. org/10.1111/j.1478-3231.2008.01934.x.

10. Mohd Hanafiah K, Groeger J, Flaxman AD, Wiersma ST. Global epidemiology of hepatitis $\mathrm{C}$ virus infection: new estimates of age-specific antibody to HCV seroprevalence. 
Hepatology. 2013; 57:1333-42. https://doi.org/10.1002/ hep.26141.

11. World Health Organization. Guidelines for the screening, care and treatment of persons with hepatitis $\mathrm{C}$ infection. Geneva: World Health Organization. 2014; 25.

12. Ott JJ, Stevens GA, Groeger J, Wiersma ST. Global epidemiology of hepatitis B virus infection: new estimates of age-specific HBsAg seroprevalence and endemicity. Vaccine. 2012; 30:2212-9. https://doi.org/10.1016/j. vaccine.2011.12.116

13. World Health Organization. Guidelines for the prevention, care and treatment of persons with chronic hepatitis B infection. Geneva: World Health Organization. 2015; XV-10.

14. NCCN.NCCN clinical practice guidelines in oncology: tyroid carcinoma (Version 2.2015). Journal of the National Comprehensive Cancer Network Jnccn. 2015. http://www. nccn.org/professionals/physician_gls/f_guidelines.asp.

15. Yang HC, Kao JH. Persistence of hepatitis B virus covalently closed circular DNA in hepatocytes: molecular mechanisms and clinical significance. Emerg Microbes Infect. 2014; 3:e64. https://doi.org/10.1038/emi.2014.64.

16. Seeger C, Ganem D, Varmus HE. Biochemical and genetic evidence for the hepatitis B virus replication strategy. Science. 1986; 232:477-84. https://doi.org/10.1126/ science.3961490.

17. Dienstag JL. Hepatitis $\mathrm{B}$ virus infection. N Engl J Med. 2008; 359:1486-500. https://doi.org/10.1056/ NEJMra0801644.

18. Blackberg J, Kidd-Ljunggren K. Occult hepatitis B virus after acute self-limited infection persisting for 30 years without sequence variation. J Hepatolo. 2000; 33:992-7. https://doi.org/10.1016/S0168-8278(00)80134-8.

19. Murakami Y, Minami M, Daimon Y, Okanoue T. Hepatitis $\mathrm{B}$ virus DNA in liver, serum, and peripheral blood mononuclear cells after the clearance of serum hepatitis B virus surface antigen. J Med Virol. 2004; 72:203-14. https:// doi.org/10.1002/jmv.10547.

20. Rehermann B, Ferrari C, Pasquinelli C, Chisari FV. The hepatitis B virus persists for decades after patients' recovery from acute viral hepatitis despite active maintenance of a cytotoxic T-lymphocyte response. Nat Med. 1996; 2:11048. https://doi.org/10.1038/nm1096-1104.

21. Sundquist K, Sundquist J, Ji J. Risk of hepatocellular carcinoma and cancers at other sites among patients diagnosed with chronic hepatitis B virus infection in Sweden. J Med Virol. 2014; 86:18-22. https://doi. org/10.1002/jmv.23754.

22. Amin J, Dore GJ, O’Connell DL, Bartlett M, Tracey E, Kaldor JM, Law MG. Cancer incidence in people with hepatitis B or C infection: a large community-based linkage study. J Hepatol. 2006; 45:197-203. https://doi. org/10.1016/j.jhep.2006.02.014.

23. Swart A, Burns L, Mao L, Grulich AE, Amin J, O'Connell DL, Meagher NS, Randall DA, Degenhardt L, Vajdic CM. The importance of blood-borne viruses in elevated cancer risk among opioid-dependent people: a population-based cohort study. BMJ Open. 2012; 2:e001755. https://doi. org/10.1136/bmjopen-2012-001755.

24. Fiorino S, Bacchi-Reggiani L, de Biase D, Fornelli A, Masetti M, Tura A, Grizzi F, Zanello M, Mastrangelo L, Lombardi R, Acquaviva G, di Tommaso L, Bondi A, et al. Possible association between hepatitis $\mathrm{C}$ virus and malignancies different from hepatocellular carcinoma: A systematic review. World J Gastroenterol. 2015; 21:12896953. https://doi.org/10.3748/wjg.v21.i45.12896.

25. Montella M, Crispo A, de Bellis G, Izzo F, Frigeri F, Ronga D, Spada O, Mettivier V, Tamburini M, Cuomo $\mathrm{O}$. HCV and cancer: a case-control study in a highendemic area. Liver. 2001; 21:335-41. https://doi. org/10.1034/j.1600-0676.2001.210506.x. 